\title{
Testing the governance-performance relationship for the Tunisian banks: a GMM in system analysis
}

\author{
Nesrine Djebali and Khemais Zaghdoudi
}

\author{
* Correspondence: djbeli.nesrine@ \\ gmail.com \\ Faculty of Law Economics and \\ Management of Jendouba, \\ University of Jendouba, Jendouba, \\ Tunisia
}

\begin{abstract}
Rationale: This study aims to contribute to settling the lack of consensus regarding the determinants of bank performance, not only by considering bank governance, but also by including factors such as CEO compensation and risk management committee. Previous literature has included bank governance and considered only large banks in their surveys. The exclusion of other factors such as small- and medium-size banks may render the findings of these studies limited in applicability.

Objective: The objective of this paper is to examine the impact of internal governance on bank performance.

Methodology: To achieve this goal, we used annual data of a sample of ten Tunisian commercial banks listed in the Tunisian Stock Exchange observed during the period 1998-2015. We use the Generalized Method of Moments (GMM) to estimate the parameters of our econometric model.

Results: Our study finds that the correlation between the size of the board of directors, the state's inclusion, and the presence of independent directors is positive and significant. On the other hand, we have found that CEO compensation, as well as foreign and institutional investors negatively affect the performance of the banks.

Conclusions and implications: Tunisian banks are invited to broaden their size through appropriate restructuring, adopt new remuneration policies and define the optimal number of directors representing the state within the board of directors. Our results suggest managerial implications that can be of great value to ensuring the success of Tunisian banks. The latter should favor a higher presence of independent directors to reduce the bank control ineffectiveness caused by having a significant number of foreign and institutional investors in the board of directors.
\end{abstract}

Keywords: Bank governance, Bank performance, Tunisian banks, GMM

\section{Introduction}

Banks are specialized companies with their own specificities; banks are more opaque than other companies, play a crucial role in financing the economy, and take on risky financial activities based on information and trust. The failure of several banking institutions in the 2000s and the financial crisis of 2007 led to weaknesses in bank

(c) The Author(s). 2020 Open Access This article is licensed under a Creative Commons Attribution 4.0 International License, which permits use, sharing, adaptation, distribution and reproduction in any medium or format, as long as you give appropriate credit to the original author(s) and the source, provide a link to the Creative Commons licence, and indicate if changes were made. The images or other third party material in this article are included in the article's Creative Commons licence, unless indicated otherwise in a credit line to the material. If material is not included in the article's Creative Commons licence and your intended use is not permitted by statutory regulation or exceeds the permitted use, you will need to obtain permission directly from the copyright holder. To view a copy of this licence, visit http://creativecommons.org/licenses/by/4.0/. 
governance, especially since the measures adopted in terms of corporate governance discredited the role and specificities of banks. Therefore, new measures were taken to strengthen the internal governance of banks, which are considered a key factor in explaining banking performance. The latter has been the subject of several research studies, yet there continues to be a lack of unanimity regarding its determinants (Adams and Mehran 2008; Laeven and Levine 2009; Belkhir 2009a,b; Pathan 2009; Lee Siew and Mansor 2015; Caspar 2016; Chenini and Jarboui 2016; Ruhul et al. 2016; Fernandes et al. 2016; Basuonya et al. 2017; Hung et al. 2017; Manas and Saravanan 2017; Ataur and Jahurul 2018; Chen et al. 2018, Haris et al. 2019).

The objective of this paper is to examine the impact of internal governance on the performance of Tunisian banks. Tunisia serves as an interesting case study since its banks are considered the most important source of funds. Domestic credit to the private sector provided by banks continues to contribute greatly to the Tunisian gross domestic product, which grew from $46.49 \%$ in 1998 , to $60.81 \%$ in 2011 , and $68.54 \%$ in 2017. ${ }^{1}$ In recent years, Tunisian banks have been subject to new governance rules, specifically Circular $\mathrm{N}^{\circ} 2006-06$ for the implementation of a system of control, Circular 2006-07 concerning the Executive Credit Committee, Circular 2006-19 concerning internal control, and Circular $\mathrm{N}^{\circ}$ 2011-06 concerning strengthening the rules of good governance in credit institutions, among others.

As far as we know, no published empirical study has simultaneously taken into account the new measures that aim to strengthen the internal governance of banks (existence of a banking risk control committee, remuneration and incentive policies, structure, and size of the board of directors, etc.), especially for the Tunisian case. This paper seeks to fill this gap and contribute to the existing literature on two levels. First, the majority of research works that deal with the effect of banking governance on performance consider large banks only. Our study enriches the existing literature by including small and medium-sized banks in the survey. We consider our study as an initiative to better understand the relationship between governance and performance in the Tunisian banking sector. This paper highlights governance factors, which are driving down the performance of Tunisian banks, with a view to proposing solutions to limit their negative effects.

Second, this study takes into consideration two dimensions of internal governance that can have an effect on the performance of banks and yet were neglected by previous works. To the best of our knowledge, there are no published empirical studies that combine, in the same econometric model, both the risk monitoring committee and CEO compensation to explain the performance of Tunisian banks. Despite the existence of numerous previous research papers exploring the topic, there continues to a lack of consensus on a definite relationship between the bank performance and its most influential factors. Thus, this study seeks to strengthen the argument of the relationship between the two by considering risk monitoring committee, compensation, and different sizes of banks.

Because the Tunisian economy is mostly financed by banks, the performance, the survival and the success of these institutions are crucial. Based on this, it is of great

${ }^{1}$ Data from database: World Development Indicators (World Bank), Last Updated: 20/12/2019. 
interest to know what contributes to success and failure of banks, and how bank executives and the state can help through policy and strategy.

To reach our aim, we used the annual data of ten Tunisian banks observed during the period 1998 and 2015. These data were collected from annual reports and the financial statements of banks, and based on it we performed an econometric model based on the Generalized Method of Moments (GMM), which seems to be the most appropriate method for estimating parameters.

The remainder of this paper is organized as follows: section 2 presents our literature review, section 3 provides an overview of the Tunisian bank system, section 4 is our empirical investigation; Section 5 discusses the results of our study, while section 6 concludes and presents some interesting implications.

\section{Literature review on governance and performance}

The literature review of the ownership structure and the board's characteristics are at the heart of this article. The characteristics of the board of directors and its supervisory role have been the subject of several studies and debates. Since the board represents stability, performance, and risk taking by banks, several recent works have sought to explain how it works. Thus, they have tried to verify how an improvement in the board's independence, composition, transparency, and accountability to investors and other stakeholders can affect the activity of banks. The literature on banking governance has shown that in addition to the structure of the board of directors, the concentration of ownership is seen as an internal governance mechanism. The concentration of ownership, whether owned by the state, institutional investors, or foreign investors, plays the role of guarantor in governance. In the banking governance system, the ownership structure also acquires great importance and its effectiveness depends on the nature of the shareholders, their objectives, and the scope of their disciplinary actions (Chenini and Jarboui 2016).

\section{Board size and Bank performance}

The board of directors is a fundamental mechanism of the internal control system that helps to discipline and define the rules of the organization. For some, the size of the board is positively related to the bank's performance. Conversely, for others, the size of the board negatively affects the performance of the bank. The most recent empirical studies on the size of the board as an internal control mechanism have revealed that a large board has a significant negative impact on the company's performance due to communication difficulties, consensus issues, and agencies. A large board may be unable to effectively oppose management, as it may face problems of non-coincidence of interests with its many members. Jensen (1993) has argued that large boards are less effective because of coordination, control, and flexibility issues in decision making, and give excessive control to CEOs. Cheng (2008) also pointed out that because of the coordination problems that can occur in a big board, the decisions made by the biggest boards can be less extreme, which reduces the level of risk.

Conversely, according to many other authors, a large board of directors can be beneficial and may increase the profitability of the company. Adams and Mehran (2003a,b) examined the relationship between board size and performance. They concluded that 
the best performing banks had larger boards. In addition, Coles et al. (2008) found that a big board affects the performance of a company, especially for companies that need more board members, such as complex companies that operate in multiple segments.

Our findings from these studies show us that with a large board of directors, there are opportunities to establish committees with specific and delegated responsibilities. This can positively affect performance. On the other hand, a small board of directors may experience problems in decision-making processes.

The bank is a company that offers its worldwide customers diversified products and services that are intensive in new technologies and private information. These characteristics require a large amount of specific knowledge. ${ }^{2}$ When the board of directors is narrow, the amount of specific knowledge decreases. This makes it more difficult for managers to supervise and implement a growth strategy. In addition, the small size of the board of directors does not allow the bank to expand the network of its relationships with new customers. This can have negative effects on the growth of its market shares.

On the other hand, other authors have shown the positive impact of the small size of the board of directors on the performance of banks. Adams (2012) supported the idea that smaller boards are more effective than larger boards because decision-making costs are lower in small groups. Pathan and Faff (2013) and Staikouras et al. (2007) found a negative relationship between the size of the board of directors and the performance of banks.

Other researchers have examined the non-linear relationship between the size of the board of directors and the banking performance. Grove et al. (2011) found a concave relationship between financial performance and board size. Andres and Vallelado (2008) came to an inverted U-shaped relation between bank performance and board size.

In this study, we consider the size of the board as a key variable of governance. Given the characteristics of Tunisian banks which have remained specialist banks in traditional activities (notably the granting of loans and the collection of deposits), we assume that a medium-sized board ( 8 to 12 members) is more efficient and better controlled. Based on the different results in these studies we suggest in the following hypothesis that:

$\mathrm{H}_{1}$ : A medium-sized board is positively linked to bank performance.

\section{Duality and Bank performance}

The chairperson of the board is the most important member as they have the power to influence the corporate governance process. For Jensen (1993), the separation of the two functions of the CEO and the chairperson of the board can increase the oversight, monitoring, and control capacity within the board. Paquerot (1997) explains that the CEO can also increase his information advantage on the board of directors and enhance his job security. In addition, few studies have examined the effects of duality on bank performance. Pi and Timme (1993) showed that the efficiency and performance of the bank's assets, as well as its measured profitability, are low when it has dual CEOs.

${ }^{2}$ Fernandes et al. (2016), p.6. 
Thus, duality can significantly increase the power of the executive in the bank's board according to Simpson and Gleason (1999). In the Tunisian context, Chenini and Jarboui (2016) studied a sample of eight banks for the period between 2000 and 2011 and found that the cumulated positions of the CEO and the chairperson of the board of directors contributed significantly to performance (expressed in terms of asset returns (ROA)). In contrast, Fogelberg and Griffith (2000) found no impact of duality on bank performance. They explained that the granting of an additional title to the manager does not necessarily increase his/her influence on the performance of the bank. According to them, it is the level of ownership that matters in this case. They further noted that the control exerted by the chairperson of the board generally has little impact on that of the chief executive officer. Following this development, we can put forward hypothesis 2 :

$\mathrm{H}_{2}$ : CEO-Chairman duality in the Board of Directors decreases the level of banking performance.

\section{Independent directors and Bank performance}

The independence of directors on the board is considered the most important measure of board effectiveness. Independent directors are defined as directors who have no social or professional relationship with the management. According to Cotter et al. (1997), a board of directors is independent when the independent directors represent more than $50 \%$ of the board. For Fogelberg and Griffith (2000), boards dominated by independent directors provide better control over bank executives. As a result, the presence of non-executive directors can increase control and effectiveness within the board of directors.

In contrast, Wang et al. (2012) have shown that a high percentage of non-executive directors have a negative impact on performance. They suggested that independent directors might have less understanding of the activities of their banks. Their work was confirmed by that of Pathan and Faff (2013). Based on a sample of 212 US banks over the period 1997-2011, they found evidence that banks that have more independent directors than others are performed less well. In this context, Griffith et al. (2002) concluded that bank performance, measured in terms of market value added (MVA), economic value added (EVA) and Tobin's $Q$, is not significantly influenced by the number of internal board directors. Andres and Vallelado (2008) revealed an inverse relationship between the proportion of independent directors and the bank's performance. They suggested that an optimal combination of independent and non-independent directors would be more effective in securing bank value than excessively independent advice. In a recent study by Fernandes et al. (2016) on the performance of banks during the financial crises of 2007-2008, their results revealed that the most successful banks during the crisis had big independent boards. Based on the literature regarding the impact of board independence on the efficiency of banking activity, we make the following assumption:

$\mathrm{H}_{3}$ : A high percentage of independent directors on the board of directors is linked to higher performance. 
State ownership and Bank performance

La Porta et al. (2002) argued that state participation in commercial banks is a sign and a clear consideration of their inefficiencies. In fact, the most important question about state ownership in banks is the availability of loans, the distribution of the loan portfolio and especially, the performance. These banks suffer from low efficiency and a high rate of nonperforming loans. As for public banks in developing countries rather than high-income countries, they are considered less profitable than their private counterparts. This may be because developing countries are less well equipped than highincome countries to cope with distortions arising from the public ownership of the banks. However, state involvement in banks operating in developing countries still plays a developmental role. Given that in our case, Tunisia is considered as a developing country, we have assumed that state participation in public banks is beneficial. It is from this that we formulate hypothesis 4 :

$\mathrm{H}_{4}$ : State participation increases the performance of banks.

\section{Foreign ownership and Bank performance}

Leightner and Lovell (1998), for a sample of banks operating in emerging markets, have shown that opening banks to foreign capital improves their performance by providing better access to technology and best governance practices. These results were confirmed by Oxelheim and Randoy (2003) work. They found that the impact of foreign directors on the performance of companies is positive. Similarly, Berger et al. (2000), found differences in efficiency between banks with strong foreign participation and those with strong local private participation. In fact, banks with foreign participation benefit from economies of scale. They also have the advantage of serving a multinational customer base by moving to other countries, primarily those with foreign affiliates of their customers (local businesses). Gulamhussen and Guerreiro (2009) examined the impact of foreign participation on bank strategy. Their results revealed that the presence of foreign administrators makes it possible to manage the total costs of the banks and to maintain the performance at a higher level. In contrast, in the Tunisian context, for a sample of eight Tunisian commercial banks, Chenini and Jarboui (2016) proved that an increase in the percentage of foreign administrators reveals a negative but insignificant impact on the performance measured by ROE and ROA. Given that foreign directors are non-board members with high experience and a good reputation, we will assume that they should enrich banking governance and ensure better performance. It is from this assumption that we formulate the following hypothesis:

$\mathrm{H}_{5}$. The percentage of foreign directors is positively associated with bank performance.

\section{Institutional investors ownership and Bank performance}

Based on a sample of US bank holding companies over the period 1997-2004, Pathan (2009) showed that a lower percentage of institutional investors is positively associated with bank risk-taking and negatively affect bank performance. In the same context, David et al. (2012) used a sample of financial firms from 30 countries that were at the center of the crisis. They defined institutional ownership as the "percentage of shares 
owned by institutional investors who have 5\% of capital". Their research showed that firms with higher institutional ownership experienced worse stock returns during the crisis period. However, Vincent et al. (2012), investigated whether risk management is related to corporate governance mechanisms. Their results demonstrated that when the percentage of a bank's shares owned by large shareholders with ownership stakes of at least $5 \%$, performance, and bank risk are affected. Following this development, we can put forward hypothesis 6.

$\mathrm{H}_{6}$ : The presence of institutional investors reduces the performance of banks.

\section{Risk monitoring committee and Bank performance}

The Risk and Oversight Committee is an independent committee of the Board of Directors. Its function is to manage, observe, and minimize the various risks the banking sector faces. Brancato et al. (2006) and Sabato (2010) showed the positive effect of the presence of a control committee in reducing bank risk and increasing profitability. In the same context, Mongiardino and Plath (2010) showed the positive effect of the risk management committee in the big banks. They found that a better management practice ensured by the risk committee ensures better stability and banking performance. As a result, we note that the monitoring of financial information, disclosure, and the monitoring of the effectiveness of the internal control process are essential to increase banking performance. Hence, our hypothesis is as follows:

$\mathrm{H}_{7}$ : The presence of a risk management committee increases bank performance.

\section{CEO incentive and Bank performance}

Executive compensation ${ }^{3}$ is considered one of the important governance mechanisms in banking and corporate theories. Through this mode of compensation, salaries ${ }^{4}$ and bonuses ${ }^{5}$ provide additional incentives to the CEO and board members. The remuneration of managers plays a central role in aligning the interests of management with those of shareholders by relying on financial incentives. Following the global financial crisis, attention has often focused on whether incentives generated by bank executive compensation programs lead to excessive risk taking and destabilization of the financial sector. In 2011, principles of sound compensation practices ${ }^{6}$ were introduced by the Financial Stability Board (FSB). The main objective of such a new regulation has been developed to harmonize executive compensation with prudent risk taking, especially in financial institutions of systemic interest. The standards require compensation practices in the financial sector to align the incentives of all employees with the long-term profitability of the company. Cerasi and Oliviero (2015), using a sample of 116 of the largest banks between 2005 and 2009, have shown that higher remuneration for CEOs is

\footnotetext{
${ }^{3}$ Executive compensation can take various forms: base salary, bonuses, stock options, restricted stock plans (share allocation), pensions, and other benefits (automobile, health care, etc.).

${ }^{4}$ The base salary is "the standard remuneration that an executive receives in terms of a contract with the company and is not linked to the performance of the company or management."

${ }^{5}$ Executives may receive bonuses that are paid annually and are generally "tied to performance measures based on accounting."

${ }^{6}$ The principles of the Financial Stability Forum and sound compensation practices have been approved by G20 leaders.
} 
Table 1 The evolution of the number of Tunisian banks

\begin{tabular}{lllllllllll}
\hline Year & $\mathbf{1 9 5 7}$ & $\mathbf{1 9 5 9}$ & $\mathbf{1 9 6 1}$ & $\mathbf{1 9 6 3}$ & $\mathbf{1 9 6 4}$ & $\mathbf{1 9 6 7}$ & $\mathbf{1 9 6 8}$ & $\mathbf{1 9 7 3}$ & $\mathbf{1 9 7 6}$ & $\mathbf{1 9 7 8}$ \\
Number & 2 & 3 & 4 & 5 & 6 & 7 & 8 & 9 & 10 & 11 \\
Year & $\mathbf{1 9 8 0}$ & $\mathbf{1 9 8 1}$ & $\mathbf{1 9 8 2}$ & $\mathbf{1 9 8 4}$ & $\mathbf{1 9 9 7}$ & $\mathbf{2 0 0 5}$ & $\mathbf{2 0 1 0}$ & $\mathbf{2 0 1 4}$ & $\mathbf{2 0 1 5}$ & $\mathbf{2 0 1 7}$ \\
Number & 13 & 14 & 17 & 18 & 19 & 20 & 21 & 22 & 23 & 23 \\
\hline
\end{tabular}

Source: Financial Statistics of the Central Bank of Tunisia, various issues (www.bct.org.tn)

associated with a lower level of financial performance over the period of the financial crisis. In addition, they have shown that CEO incentives are associated with lower stocks of returns and greater volatility. In the same context, by studying a sample of international banks from 2006 to 2014, Cerasi et al. (2017), assessed the impact of the compensation practices of bank CEOs for a post-crisis period. They looked at how the compensation structure of bank CEOs changed after the introduction of the Principles and Standards of Good Compensation Practices in 2011. Their results showed that the share of variable compensation was less positively correlated with short-term profit and negatively correlated with bank risk. Finally, Sanjai (2017) argued that the incentives generated by executive compensation programs lead to excessive risk taking by banks contributing to the 2008 financial crisis, as well as lower profitability. In our model, we will calculate gross executive compensation in relation to total assets. We will examine the interaction between CEO compensation and bank performance. At this time, we make the following hypothesis:

$\mathrm{H}_{8}$ : CEO compensation decreases banking performance.

\section{An overview of the Tunisian Bank system}

Since its independence in 1956, Tunisia's economy has been financed mainly through debts. The activities of the whole financial system remain concentrated in the banking sector, which is considered the main provider of funds intended to meet the needs of different economic agents. The evolution of the number of Tunisian banks is presented in Table 1.

In 2017, the Tunisian banking sector was made up of 23 resident banks, twenty of them were conventional ${ }^{7}$ and three Islamic. ${ }^{8}$ It experienced two major periods characterized by different regulations delimiting banking activities. From independence until 2001, it was the law of December 1967 that regulated the banking profession. This law insisted on banking specialization. Commercial banks were mainly specialized in granting short-term loans, unlike investment banks, which granted medium- and long-term loans. During this first period, the adopted monetary policy was essentially based on controlling the liquidity of the banks and the orientation of credits towards sectors considered strategic (agriculture, export, tourism, etc.).

${ }^{7}$ Arab Tunisian Bank (ATB), French-Tunisian Bank (BFT), National Agricultural Bank (BNA), Attijari Bank (ATTIJARI BANK), Bank of Tunisia (BT), Amen Bank (AMEN BANK), CitiBank (CITI BANK), Arab Banking Corporation (BANK ABC), Arab International Bank of Tunisia (BIAT), Tunisian Banking Company (STB), Stusid Bank (STUSID BANK), Banking Union for Trade And Industry (UBCI), International Union of Banks (UIB), Bank of Housing (BH), Tunisian Solidarity Bank (BTS), Qatar National Bank (QNB), TunisianKuwaiti Bank (BTK), Bank of Tunisia and Emirates (BTE), Bank For Financing Small and Medium Enterprises (BFPME), Tunisian-Libyan Bank (BTL).

${ }^{8}$ Zitouna Bank (BZ), Al Baraka Bank Tunisia (AL BARAKA BANK) and Wifack International Bank (WIB). 
From 2001, with the publication of the new law $\mathrm{N}^{\circ} 2001-65$ of July 10, 2001, relating to credit institutions, which was in turn modified and supplemented by Law $\mathrm{N}^{\circ} 2006-$ 19 of May 2, 2006, and since banks have been transformed into universal banks, Tunisia no longer classifies banks based on specialization. This new law allows them to diversify their businesses. The bank can carry out operations related to its activities such as advice and assistance in wealth management, financial management, financial engineering, and all other services intended to facilitate the creation, development, and restructuring of enterprises. The bank can also take equity stakes in existing or new enterprises.

This new law has made the Tunisian banking sector more responsible for financing the national economy. Banks continued to support the economy despite the difficult national environment after the 2011 people's revolution. Loans granted to customers and deposits collected are shown in Fig. 1.

Credit to the economy has continued to increase from 1 year to another, going from 41,411.8 MTD in 2011 to 67,809.7 MTD in 2017, and constitute the main component of the assets of the Tunisian banking system. To boost investment after the revolution, the Central Bank of Tunisia lowered its key rate to facilitate access to credit. At the same time, the social movements that arose have imposed wage increases, increasing the debt capacity of households. These two factors contributed to the rise in the credit given.

The growth of credit is not dissociated from that of deposits, which constitute the main component of the resources of Tunisian banks. Deposits were mainly collected from individuals who benefited from the increase in the number of bank branches, but also from the lack of investment alternatives (for example the unfavorable situation for placement on the Tunisian stock exchange).

Credit and deposit growth show that Tunisian banks continue to rely on traditional banking intermediation despite the exhaustion of the factors that have supported them for a long time. This strategy has affected the main indicators of the Tunisian banking sector, which are given in Table 2.

From 2011, Tunisian banks have found it difficult to drain deposits given the crisis of low confidence that led to massive withdrawals despite the adoption of a policy to expand the network of bank branches. During this time, 77 new bank branches opened resulting in an increase of the total number of branches from 1827 in 2016 to 1904 branches in 2017. ${ }^{9}$ The ratio of credits to deposits, which measures the liquidity risk of banks, is now higher than 100\% as shown in Fig. 2.

This disproportionate increase between loans and deposits has affected the quality of assets of the Tunisian banking sector, which has been deteriorating. The ratio of nonperforming bank loans to total gross loans increased from $11.3 \%$ in 2011 to $14.4 \%$ in 2016. ${ }^{10}$ This deterioration is explained by the weakening of the economy following the international financial crisis of 2007, the revolution of 2011, and the inability of certain sectors and companies to honor their commitments. In particular, the tourism sector, which contributed significantly to the country's GDP, suffered from structural

\footnotetext{
${ }^{9}$ Annual report of Tunisia's Professional Association of Banks and Financial Institutions (2017), p.46. (www. apbt.org.tn).

${ }^{10}$ These percentages were taken from database: World Development Indicators (World Bank), 01/03/2017.
} 


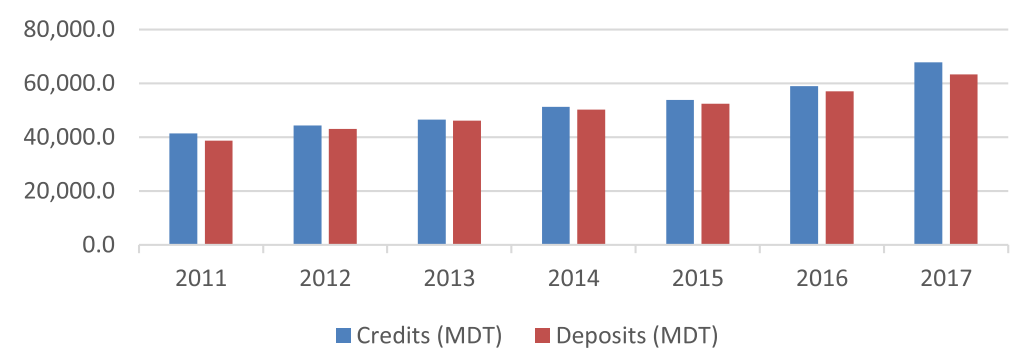

Fig. 1 The evolution of credits and deposits (in MTD (Million Tunisian Dinars))

problems. This has become a burden for banks since several tourism projects have failed to repay their debts.

Since 2008, the Central Bank of Tunisia has guided banks towards an intensification of the provisioning of classified claims. Banks have collectively applied themselves to consolidating their stable and long-term resources in order to increase their financial solidity by mitigating the credit risks. This consolidation allows them to increase their lending capacity, to meet regulatory requirements in terms of equities relative to the level of risk supported, as well as to maintain a dynamic growth of their activity.

Over the 2011-2017 period, the sector's capital adequacy ratio (CAR $)^{11}$ was maintained at an average level of $8.2 \%$. The results of several banks are affected by the economic slowdown and mainly by the level of risk that required an additional provisioning effort, in accordance with the Central Bank circular N²012-02, which aims to face the risk of default by companies in difficulty following the deterioration of the national economic situation.

Although they improved, the return on equity (ROE) and return on assets (ROA) of banks remained low. ROE increased from $6.3 \%$ in 2011 to $13.32 \%$ in 2017 . ROA doubled from $0.6 \%$ in 2011 to $1.2 \%$ in 2017 . This improvement is explained by the easing of the provisioning policy in 2014, which was less pronounced compared to the two previous years. This has had the effect of stimulating the activity of resident banks as shown in Fig. 3, which traces the evolution of their net banking income that increased to 4127.40 MTD in 2017. The Central Bank of Tunisia raised the key rate twice in 2013.

Figure 4 clearly shows the importance of the interest margin compared to the other components; it accounts for around $60 \%$ of the global net banking income.

The interest margin comes from traditional intermediation activities (mainly granting loans and collecting deposits). It benefited from the increase of the money market rate and better control of deposits' cost.

From 2011, the net banking income has grown less quickly than the operating costs of Tunisian banks. To ease social tension, Tunisian banks have revised their staff costs upwards. This led to a drop in the operating coefficient of the banking sector, which went from $51.1 \%$ in 2011 to $47.4 \%$ in 2017 . On the other hand, the net banking income of Tunisian banks has grown at a higher rate than that of the number of bank employees. This increase allowed the evolution of the productivity ratio, which rose regularly from 110.2 TTD in 2011 to 211.7 TTD in 2017.

${ }^{11}$ The capital adequacy ratio $(\mathrm{CAR})=$ Equities / total assets. 
Table 2 The main indicators of the Tunisian banking system

\begin{tabular}{|c|c|c|c|c|c|c|c|}
\hline Indicators & 2011 & 2012 & 2013 & 2014 & 2015 & 2016 & 2017 \\
\hline \multicolumn{8}{|l|}{ Profitability } \\
\hline $\mathrm{ROA}(\%)$ & 0.60 & 0.60 & 0.30 & 0.80 & 0.90 & 1.00 & 1.20 \\
\hline ROE (\%) & 6.30 & 7.40 & 3.80 & 11.30 & 10.05 & 11.12 & 13.32 \\
\hline \multicolumn{8}{|l|}{ Risk } \\
\hline CDR (\%) & 75.33 & 72.61 & 73.50 & 75.44 & 79.07 & 71.57 & 72.44 \\
\hline LIQR (\%) & 106.91 & 102.92 & 100.78 & 101.95 & 102.88 & 103.34 & 107.08 \\
\hline \multicolumn{8}{|l|}{ Stability } \\
\hline Bank nonperforming loans to total gross loans (\%) & 11.3 & 12.8 & 14.5 & 13.8 & 14.5 & 14.4 & \\
\hline \multicolumn{8}{|l|}{ Solvency } \\
\hline CAR (\%) & 8.73 & 8.15 & 6.55 & 7.14 & 9.52 & 8.55 & 8.74 \\
\hline \multicolumn{8}{|l|}{ Exploitation } \\
\hline Coefficient of exploitation (\%) & 51.1 & 50.3 & 47.3 & 48.4 & 49.1 & 48.9 & 47.4 \\
\hline \multicolumn{8}{|l|}{ Productivity } \\
\hline Productivityratio (in $T D^{b}$ ) & 110.2 & 120.4 & 134.1 & 144.1 & 151.5 & 164.5 & 211.7 \\
\hline
\end{tabular}

\section{Empirical investigation}

In this section, we begin by presenting data and methodology. Second, we specify our econometric model and define all variables used in this study. Finally, we present and discuss the empirical findings.

\section{Data and methodology}

To identify the effect of bank governance on bank performance, we used a database of ten Tunisian banks observed over the period 1998-2015. Accounting and financial data were collected directly from banks' financial statements, while data on governance was extracted from their annual reports.

Among the 23 resident banks, 10 of them are large and listed on the Tunisian Stock Exchange. These include BIAT, BNA, Attijari Bank, STB, Amen Bank, BH, UIB, BT, ATB, and UBCI. These banks differ in the ownership structure of their capital. The majority of the capital of BNA, BH, and STB is owned by the Tunisian state, while that of BIAT, BT and Amen Bank are owned by Tunisian private banks, and of Attijari Bank, ATB, UIB, and UBCI is foreign capital.

In 2017, these ten banks alone monopolized a share of $86.13 \%$ of total assets, $87.31 \%$ of granted loans, $88.39 \%$ of collected deposits, and $88.29 \%$ of the net banking income of all banks. They employ 16,477 people representing $78.96 \%$ of the total banking workforce, which equals 20,862. According to the Central Bank of Tunisia (2018), these banks have $1510^{12}$ bank branches, representing $79.31 \%$ of the total number of bank branches, which is equal to $1907 .{ }^{13}$

These indicators show that the Tunisian economy is mainly financed by these 10 banks, which are the most active and dynamic banks in the country, and can, therefore, represent the Tunisian banking sector. For this reason, we have retained, in this paper,

\footnotetext{
${ }^{12}$ Financial Statistics of Central Bank of Tunisia, $N^{\circ} 201$, January 2018, p.28.

${ }^{13}$ All these percentages are made by authors from Annual report of Tunisia's Professional Association of Banks and Financial Institutions (2017).
} 


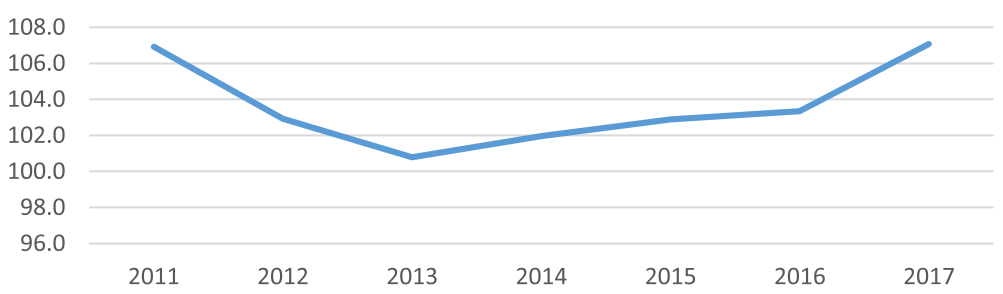

Fig. 2 The evolution of the credits to deposits ratio expressed in percentages

these banks as our sample to examine the impact of governance on the performance of Tunisian banks.

Tunisia has several circulars which aim to install a whole system of good governance within the banks, including circular $\mathrm{N}^{\circ} 2006-06$ relating to the installation of a system of control of conformity, circular 2006-07 relating to the Executive Credit Committee and circular 2006-19 relating to internal control, and others. However, this regulatory framework has not improved their management. Consequently, in 2011,

"The supervisory authority came to consolidate good governance practices in the banking system through the publication of the circular to Credit Institutions $\mathrm{n}$ 。 2011-06 of May 20, 2011 relating to the strengthening of the rules of good governance in credit institutions. This circular defines the principles of good governance that credit institutions must observe in order to establish transparent, healthy and prudent management guaranteeing their sustainability and protecting the interests of shareholders, creditors, depositors and employees. The circular reinforced the powers of the board of directors of credit institutions and thus created a framework favoring a balanced distribution of power and decision-making between the management body and the board of directors." ${ }^{14}$

The provisions of this new circular are mainly ${ }^{15}$ :

- The nominative composition of the board of directors of credit institutions, the rules of its operation, and the professional career of its members;

- The new responsibilities of the committees emanating from the board of directors of credit institutions: the risk committee, the executive credit committee, and the permanent internal audit committee;

- Establishing the codes: the governance code and the code of ethics establishing the principles and rules of good professional conduct;

- The implementation of a formalized and written policy on the management of conflicts of interest;

- The remuneration of the members of the board, the management body, and senior management;

\footnotetext{
${ }^{14}$ Annual report of Tunisia's Professional Association of Banks and Financial Institutions (2011), p.23-24. (www.apbt.org.tn).

${ }^{15}$ Annual report of Tunisia's Professional Association of Banks and Financial Institutions (2012), p.28. (www. apbt.org.tn).
} 


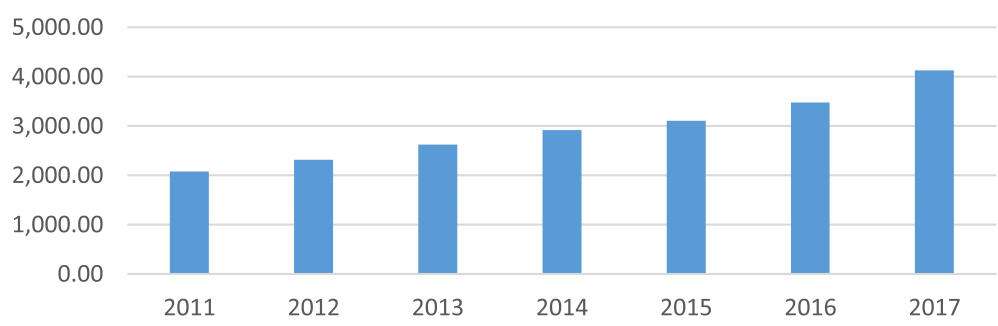

Fig. 3 The evolution of the net banking income (NBI) of Tunisian banks (in MTD)

- The definition of the methods of transmission of information by the management body to the boards and committees.

The Central Bank of Tunisia has come up with multiple initiatives in recent years: new composition of the board of directors, separation of control and decision-making powers, clarification of the role and the composition of the executive credit committee, the risk committee and the permanent internal audit committee, compensation policy for managers, participation in the development of a guide to good governance practices for Tunisian companies, etc. Banks are now subject to new rules of good governance. The objective of this article is to examine the effect of the new measures taken to strengthen internal governance mechanisms on the performance of Tunisian banks that continue to finance the national economy despite a difficult national environment.

In corporate governance, traditional econometric methods such as ordinary least square, fixed effect, and quasi-generalized least squares do not allow us to obtain efficient estimates. To solve this problem, we use the generalized method of moments (GMM) proposed by Arellano and Bond (1991) and later developed by Arellano and Bover (1995) and Blundell and Bond (1998). Specifically, we use the GMM in system (SGMM) since it has been proved to improve the GMM estimator in the first differenced (DGMM) model in terms of bias and root mean squared error. This method makes it possible to provide solutions to the problems of simultaneity bias, reverse causality (especially between board ownership structure and profitability) and any omitted variables. Moreover, it controls the individual and temporal specific effects and solves the problem of endogeneity.

Furthermore, applying the method of (GMM) on panel data has another advantage: it generates the instruments from the explanatory variables (Arellano and Bover (1995)). This is not the case for other traditional methods of instrumental variables such as 2SLS and

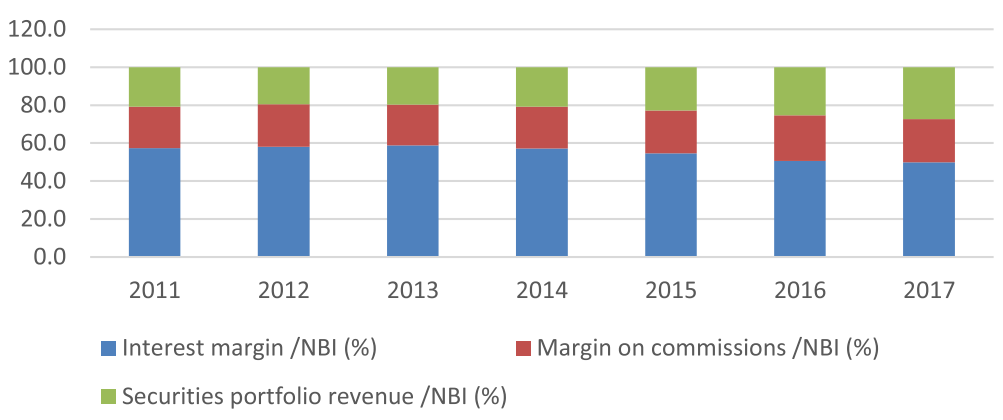

Fig. 4 The evolution of the structure of the NBI of Tunisian banks (in \%) 
3SLS - these require the choice of theoretical instrumental variables to be correlated with the explanatory variables, but uncorrelated with the residual, which is difficult to find.

\section{Model and variable definitions}

To investigate the effects of internal governance on bank performance, we referred to previous studies that tested this relationship (Fallatah and Dickins 2012; García et al. 2009; Hakimi et al. 2017; etc.). In this paper, the econometric model to be tested is inspired by Chenini and Jarboui's (2016) work. It can be presented in the following form:

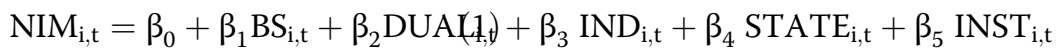

$$
\begin{aligned}
& +\beta_{6} \mathrm{EXT}_{\mathrm{i}, \mathrm{t}}+\beta_{7} \mathrm{CRO}_{\mathrm{i}, \mathrm{t}}+\beta_{8} \mathrm{COMP}_{\mathrm{i}, \mathrm{t}}+\beta_{9} \mathrm{CDR}_{\mathrm{i}, \mathrm{t}}+\beta_{10} \mathrm{LIQR}_{\mathrm{i}, \mathrm{t}} \\
& +\beta_{811} \text { SIZE }+\stackrel{\AA}{A} \mathrm{E}_{i, t}
\end{aligned}
$$

The definitions and measurements of the variables used in this model are presented in Table 3.

\begin{tabular}{|c|c|c|c|}
\hline Variables & Definitions & Measurements & Sources \\
\hline \multicolumn{4}{|c|}{ Dependent Variable } \\
\hline NIM & Net Interest Margin & $\begin{array}{l}\text { (Received Interest - Paid Interest) / } \\
\text { Total Assets }\end{array}$ & Hakimi et al. (2017). \\
\hline \multicolumn{4}{|c|}{ Bank - specific } \\
\hline SIZE & Bank Size & Ln (TotalAssets) & Hakimi et al. (2017). \\
\hline CDR & Credit Risk & Total Loans/ Total Assets & $\begin{array}{l}\text { Hakimi and Zaghdoudi } \\
\text { (2017), Zaghdoudi and } \\
\text { Hakimi (2017), Hakimi et } \\
\text { al. (2017). }\end{array}$ \\
\hline LIQR & Liquidity Risk & TotalCredit /Total Deposit & $\begin{array}{l}\text { Zaghdoudi and Hakimi } \\
\text { et al. (2017). }\end{array}$ \\
\hline \multicolumn{4}{|c|}{ Corporate Governance } \\
\hline BS & Board Size & Number of directors on the board & Chenini and Jarboui (2016). \\
\hline DUAL & Duality & $\begin{array}{l}\text { Binary variable that takes } 1 \text { when } \\
\text { the executive director is also chairman } \\
\text { of the board and } 0 \text { otherwise. }\end{array}$ & $\begin{array}{l}\text { Griffith et al. (2002), } \\
\text { Adams and Ferreira } \\
\text { (2007), Pathan (2009), } \\
\text { Chenini and Jarboui } \\
\text { (2016) }\end{array}$ \\
\hline IND & Board Independence & $\begin{array}{l}\text { Number of independent directors / } \\
\text { total number of directors on the } \\
\text { board. }\end{array}$ & Fernandes (2017). \\
\hline STATE & $\begin{array}{l}\text { Presence of directors } \\
\text { representing the State } \\
\text { on the board of directors }\end{array}$ & $\begin{array}{l}\text { Number of directors representing } \\
\text { the state / total number of directors } \\
\text { on the board. }\end{array}$ & Chenini and Jarboui (2016). \\
\hline EXT & $\begin{array}{l}\text { Percentage of foreign } \\
\text { directors. }\end{array}$ & $\begin{array}{l}\text { Number of foreign directors / total } \\
\text { number of directors on the board. }\end{array}$ & Chenini and Jarboui (2016). \\
\hline INST & $\begin{array}{l}\text { Percentage of institutional } \\
\text { investors }\end{array}$ & $\begin{array}{l}\text { Percentage of investors holding 5\% } \\
\text { or more of the capital. }\end{array}$ & Chenini and Jarboui (2016). \\
\hline CRO & Risk Monitoring Committee & $\begin{array}{l}\text { Takes } \\
\text { 1: Existence of a risk management } \\
\text { committee. } \\
0 \text { : No existence of a risk management } \\
\text { committee. }\end{array}$ & Aebi et al. (2012). \\
\hline COMP & CEO Compensation & $\ln \left(C E O \frac{\text { Compensation }}{\text { Total }}\right.$ Assets $)$ & $\begin{array}{l}\text { Caspar (2016), Cerasi } \\
\text { et al. (2017). }\end{array}$ \\
\hline
\end{tabular}

Table 3 Variable definitions and measurements 


\section{Results and discussions}

In this section, we start by presenting the descriptive statistics of all variables used in our econometric model. After that, we present their correlation matrix. In fine, we display and interpret our empirical results.

The objective of this article is to explore the effect of internal governance on bank performance based on a sample of ten Tunisian banks observed over a period of eighteen years (from 1998 to 2015). For this, descriptive statistics give us an idea about the average value, minimum value, maximum value, and standard deviation of each variable. Table 4 gives descriptive statistics of all variables used in this study.

For the dependent variable, the average net interest margin (denoted as Nim) value is about $2.8 \%$, with a standard deviation of $1.1 \%$, a minimum value of $0.4 \%$, and a maximum value of $5.9 \%$.

With regard to the banking governance mechanism, the size of the board of directors (denoted as BS) has an average value of 11 members. The maximum and minimum values are respectively about 5 and 14 members on the board. Tunisian banks are characterized by large boards of directors, which is in line with Tunisian good governance guidelines. ${ }^{16}$ The size of the board is expected to improve the performance of Tunisian banks. Duality (denoted as Dual) is a binary variable; its average value is equal to 0.594 with a standard deviation of 0.492 . Almost, $60 \%$ of our sample of banks is characterized by a dual structure in which the executive director is also the chairperson of the board. This result is in accordance with the guide of governance of Tunisian companies for the year (2008). This guide recommends Tunisian companies to separate the functions of the officer and the chairperson of the board of directors.

For the percentage of independent directors (denoted as Ind) in the total number of directors on the board, its average value is equal to $6.6 \%$, which is very weak. Our sample of banks does not conform to the good governance practice guidelines of Tunisian companies, ${ }^{17}$ which recommended that at least one-third of the members of the board of directors be independent. Regarding the presence of directors representing the state (denoted as State) on the board of directors, the value recorded is an average of $14.9 \%$ with a maximum value of $54.5 \%$. The percentage of foreign directors on the board

Table 4 Descriptive Statistics

\begin{tabular}{llllll}
\hline Variable & Obs & Mean & Std. Dev. & Min & Max \\
\hline Nim & 180 & 0.028 & 0.011 & 0.004 & 0.059 \\
BS & 180 & 11.039 & 1.511 & 5 & 14 \\
Dual & 180 & 0.594 & 0.492 & 0 & 1 \\
Ind & 180 & 0.066 & 0.106 & 0 & 0.444 \\
State & 180 & 0.149 & 0.195 & 0 & 0.545 \\
Ext & 180 & 0.226 & 0.244 & 0 & 0.777 \\
Inst & 180 & 0.369 & 0.204 & 0 & 0.875 \\
Cro & 180 & 0.511 & 0.501 & 0 & 1 \\
Comp & 100 & 0.069 & 0.059 & 0.003 & 0.257 \\
Cdr & 180 & 0.746 & 0.130 & 0.030 & 0.964 \\
Liqr & 180 & 1.179 & 0.366 & 0.551 & 2.597 \\
Size & 180 & 14.877 & 0.620 & 13.742 & 16.169 \\
\hline
\end{tabular}

Source: Author's calculations based on data from the banks' annual reports 
of directors (denoted as Ext) is equal on average to $22.6 \%$ with a maximum value of $77.7 \%$ and a standard deviation value of $24.4 \%$. The presence of institutional investors (denoted as Inst) on the board of directors has an average value of $36.9 \%$, with standard deviation and maximum values of $20.4 \%$ and $87.5 \%$ respectively. This result reveals that the percentage of investors holding $5 \%$ or more of the capital of Tunisian banks is strong. The presence of institutional investors on the boards of Tunisian banks is expected to increase their performance.

With regard to the risk monitoring committee variable (denoted as Cro), 51.1\% of our sample banks have a banking risk management and monitoring committee, which can reduce risks and enhance the performance of banks. Finally, the CEO compensation variable (denoted as Comp) has an average value of $6.9 \%$, with a maximum value of $25.7 \%$, a minimum value of $0.3 \%$, and a standard deviation value of $5.9 \%$. The average value of this variable is low, which discourages managers. Its effect on the performance of Tunisian banks is expected to be negative. This is why we suggest that Tunisian banks review their remuneration and incentive policies to strengthen their internal governance.

Concerning the other variables introduced in our econometric model, statistics displayed in Table 3 show that the average value of credit risk (denoted as Cdr) of Tunisian banks is $74.6 \%$ with a maximum value of $96.4 \%$ and a minimum value of $3 \%$. In this paper, liquidity risk (denoted as Liqr) is measured by the ratio of Total Loans to Total Assets. Over the selected period, the liquidity risk of Tunisian banks is equal, on average, to $117.9 \%$, with maximum and minimum values of $259.7 \%$ and $55.1 \%$ respectively. In 2018, the Central Bank of Tunisia published a new circular ${ }^{18}$ that obliges banks to respect a new ratio of 'credits to deposits'. Such a ratio should not exceed $110 \% .{ }^{19}$ This reform does not intend to institute a target ratio of $110 \%$, but rather to encourage banks that display very high ratios (having reached a rate of 150\%) to gradually reduce their liquidity risks. In the absence of a real risk control committee, these two major credit and liquidity risks can adversely affect the performance of Tunisian banks. On average, the size of our sample of Tunisian banks (denoted as Size) is equal to 14.877. Compared to other banks in developing countries, the majority of Tunisian banks are small- and medium-sized. This may negatively affect their performance since Tunisian banks are likely to suffer from strong competition in the local market from foreign banks, especially European ones.

Before presenting and interpreting the econometric results, we first check the possible multicollinearity between the variables of our model. Multicollinearity can distort the accuracy of the estimation of the regression coefficients and make their estimated values sensitive to small fluctuations in the data (Bourbonnais 2009). To do this, we refer to the correlation matrix displayed in Table 4, which detects the correlation nature (positive or negative) and the correlation level (low or high) between the different variables.

Table 5 shows that State is highly correlated with three variables: Ext, Inst and Comp. Except for these three cases, the remaining variables are weakly correlated, hence the existence of a multi-collinearity problem.

\footnotetext{
${ }^{18}$ On September 07, 2018, the CBT issued a statement release introducing a new circular stipulating the obligation for banks to respect the 'credits / deposits' ratio.

${ }^{19}$ Banks with ratios less than or equal to $110 \%$ will not be affected by this reform.
} 


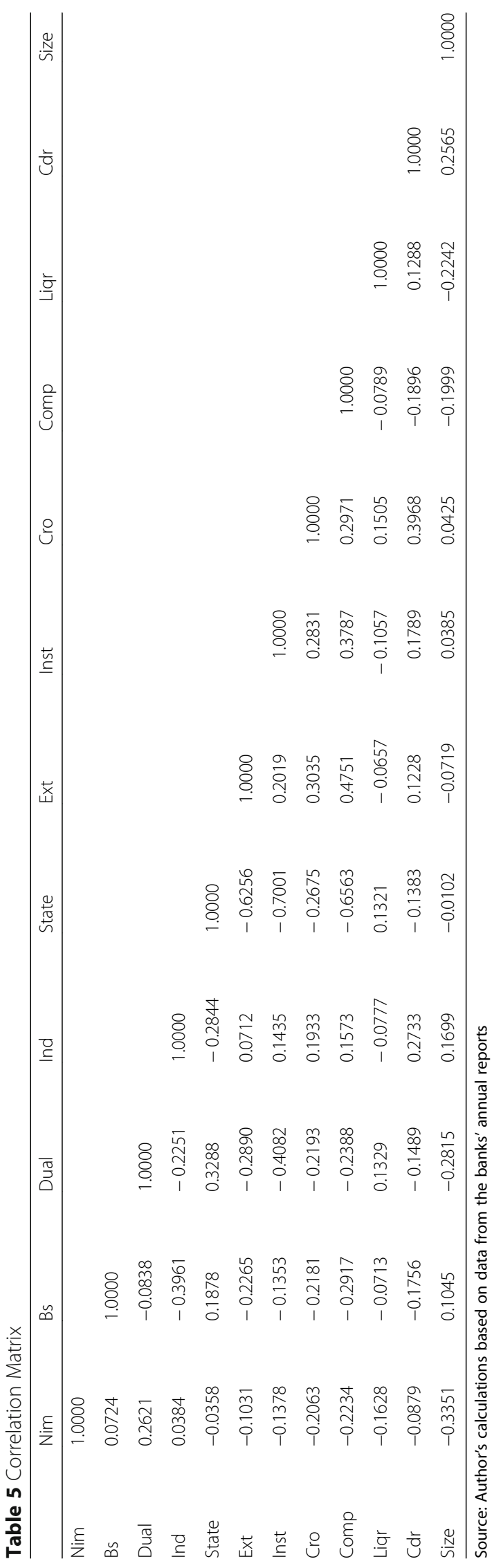


Table 6 below presents the results of the effect of bank governance on bank performance measured by NIM. It is worth recalling that in this study, we use the GMM method, specifically, the GMM in system (SGMM). The test for autocorrelation is made according to the statistics of AR (1) and AR (2). Both AR (1) and AR (2) confirm the absence of an autocorrelation problem since their $P$-values are greater than $5 \%$. The validity of the instrumental variables is checked using the Sargan test, which confirms the validity of instrumental variables since its $P$-value is greater than $5 \%$.

Empirical results displayed in Table 6 show that BS has a positive and significant effect at the $5 \%$ level of significance on the performance of Tunisian banks, verifying the hypothesis $\mathrm{H}_{1}$. This result can be elucidated by the benefits that can be added by adopting a large board of directors. On average, the size of the board of directors of our sample is equal to 11 members. Our result confirms Basuonya et al.'s (2017) work, which revealed a positive impact between the size of the board of directors and the performance measured by Tobin's Q. Ruhul et al. (2016) also found that the board size had robustly significant and positive effects on the efficiency and the performance of Australian banks during the period 1999-2013.

However, our finding contradicts those of Chenini and Jarboui (2016) who found a negative relationship between the size of the board and the performance of banks. A large-sized board promotes leadership dominance and creates potential conflicts of interest between directors and managers. Some studies have pointed to the fact that turnover size can negatively affect bank performance.

Table 6 Results of Generalized Method of Moments (GMM) in system: (Dependent Variable: NIM)

\begin{tabular}{lllll}
\hline Nim & Coef. & Std. Err. & Z & $P>z$ \\
\hline NimL1. & 0,744 & 0,394 & 1890 & $0,059^{*}$ \\
BS & 0,004 & 0,002 & 2360 & $0,018^{* *}$ \\
Dual & 0,001 & 0,001 & 1370 & 0,170 \\
Ind & 0,003 & 0,001 & 2460 & $0,014^{* *}$ \\
State & 0.827 & 0.352 & 2.347 & $0.019^{* *}$ \\
Ext & $-0,694$ & 0,285 & -2430 & $0,015^{* *}$ \\
Inst & -1321 & 0,541 & -2440 & $0,015^{* *}$ \\
Cro & 0,011 & 0,007 & 1590 & 0,111 \\
Comp & -1.628 & 0.835 & -1.95 & $0.051^{*}$ \\
Size & $-0,201$ & 0,079 & -2.535 & $0,012^{* *}$ \\
Liqr & $-0,002$ & 0,018 & $-0,130$ & 0,896 \\
Cdr & $-0,008$ & 0,003 & -3050 & $0,002^{* * *}$ \\
-cons & 0,325 & 0,134 & 2430 & $0,015^{* *}$ \\
AR (1) & -0.4951 & & \\
$P$-value & & 0.6205 & & \\
AR (2) & & 0.1220 & & \\
P-value & 0.9028 & & \\
Sargan Test & & 6.7831 & \\
P-value & 0.6987 & \\
Observations & 180 & & \\
\hline
\end{tabular}

***, ${ }^{* *}$ and $*$ indicate level of significance at $1 \%, 5 \%$ and $10 \%$ respectively Source: Author's calculations based on data from the banks' annual reports 
Manas and Saravanan (2017) found that the relationship between the board size and the performance of banks is curvilinear. An increase in board size is associated with better bank performance within both low and high board size ranges. Alternatively, an increase in the board's size is negatively associated with bank performance in the intermediate board size range.

Findings also reveal that the presence of more financial experts serving as independent directors increases the performance of Tunisian banks. Hence, our hypothesis $\mathrm{H}_{3}$ is accepted. Independence can improve management control and oversight. The bank's independent directors should then help balance the different objectives of a broader set of stakeholders, including creditors, and not focus solely on the interests of shareholders. In Tunisia, starting from 2016, structural changes included the addition of independent directors to boards of directors. This change has now been extended to all banks under "Art 47" of the new banking law. Other authors found results similar to ours (Pathan and Faff 2013; Fernandes et al. 2016; Ataur and Jahurul 2018).

Empirical results displayed in Table 6 prove the importance of the state participation on the board of directors of banks, since it has a positive and significant impact at the $5 \%$ level of significance on the performance of Tunisian banks. Consequently, hypothesis $\mathrm{H}_{4}$ is accepted. The directors representing the state preserve the interests of the various shareholders and urge the managers to ensure better performance. Public ownership of banks helps guarantee greater efficiency where the state holds significant shares of their capital. However, we have noted that the state plays the role of a regulator that ensures the protection of the collective well-being. Therefore, Tunisian banks characterized by the presence of state administrators are more efficient. In Tunisia, in 2015, the three state-owned Tunisian banks STB, ${ }^{20}$ BNA, and BH represented 38\% of total assets. They have recently attracted the attention of many private investors, who have increased their stake in these banks for strategic or financial purposes. In 2015, in order to carry out a radical restructuring for the benefit of public banks, various reforms were introduced. The objective of such a restructuring was to make public banks more competitive and put them in a better position to finance the economy. Our findings contradict those of La Porta et al. (2002), Chen et al. (2018), and Haris et al. (2019). La Porta et al. (2002) stated that in developing countries, state participation in commercial banks might cause inefficiency.

Chen et al. (2018) showed that government banks with politically connected CEOs experienced significantly higher loan default rates and worse operating performance during the 2007 financial crisis than those without politically connected CEOs. However, these politically connected CEOs were less likely to be penalized for the poor performance of their banks than others. Haris et al. (2019) affirmed that bank profitability is negatively affected by the presence of politically connected directors on the board.

Our results show that the presence of foreign investors is not beneficial for Tunisian banks, since it has a negative and significant effect at the $5 \%$ level of significance on their performance, rejecting the hypothesis $\mathrm{H}_{5}$. Foreign administrators are generally unaware of the Tunisian economic reality and may have difficulties implementing and applying their governance concepts to the specific case of Tunisian commercial banks.

\footnotetext{
${ }^{20}$ As part of its recapitalization plan, STB decided to proceed with a capital increase for a value of 756 TTD Such an amount will enable the bank to respect the solvency ratios required by the Central Bank of Tunisia and ensure its sustainability (a solvency ratio of about $12.7 \%$ for the year 2015).
} 
Our result is in line with the findings of several studies such as Chenini and Jarboui (2016).

Theoretically, institutional investors are often considered as active investors, able to use their voting power to encourage good governance practices in the companies in which they invest. On the contrary, our empirical results show that institutional investors have not played their role, since they have a negative and significant impact at the $5 \%$ level of significance on the performance of Tunisian banks, verifying the hypothesis $\mathrm{H}_{6}$. In our sample, the presence of institutional investors on the board of directors leads to less effective control and consequently decreases bank performance. Our results refute Duggal and Millar's (1999) work and Pinto (2006) in which institutional investors can influence the decisions of managers and positively affect the performance of banks.

Findings displayed in Table 6 prove that the CEO Compensation significantly reduces the performance of Tunisian banks, verifying the hypothesis $\mathrm{H}_{8}$. In the majority of Tunisian banks, CEO compensation is not well established and it does not involve the managers, which increases their risk-taking behavior. This is why we suggest that $\mathrm{Tu}$ nisian banks revise their remuneration and incentive policies to reinforce internal governance. Since the 2007 crisis, new governance rules specific to banks have been adopted in the majority of developed countries, including the definition of an appropriate remuneration policy. Other authors found results similar to ours (Cerasi and Oliviero, 2015; Bhagat 2017). However, our results differ from those of Lee Siew and Mansor (2015). Studying the relationship between directors' remuneration, governance, and performance for the Malaysian banks over the period 2003-2011, Lee Siew and Mansor (2015) found a positive nexus between directors' remuneration and performance. Furthermore, Granger causality tests proved that directors' remuneration causes bank performance.

Results given in Table 6 indicate that the size of banks is negatively correlated with bank performance at the $5 \%$ level of significance. This result can be explained by the small and medium size of Tunisian banks, which give primacy to their risky credit activities. Over the selected period, the assets of Tunisian banks are dominated by bank loans that represent an average of $74.6 \%$. Given the importance of the ten banks retained in our study, which are the main providers of liquidity, the Tunisian economy may suffer from financial system risk, which is an important issue in economic and financial systems (Kou et al. 2019), if these banks fail to revise this primacy accorded to traditional intermediation.

Tunisian banks are invited to increase their size since large size provides several advantages. Such bank size reassures and secures the bank's customers and increases its negotiation margins. It allows the bank to target a wide variety of customers located around the world. This permits the bank to spread the risk. Likewise, a large bank generally has a network of ATMs enabling it to collect resources at a lower cost.

Other studies show that the relationship between size and performance is not linear. It is explained by a threshold effect. The result found in this paper can also be clarified by the fact that Tunisian banks have not yet reached a critical size beyond which size would have a positive effect on performance. In the same breath, Barros et al. (2007) and Athanasoglou et al. (2008) showed that the nexus between size and performance is non-linear, and that performance increases with size. 
Findings reveal also that only credit risk has a negative and significant effect on bank performance. A high level of credit risk reduces the performance of banks. This result is explained by the intensification of competition between financial institutions, which have engaged in risky activities. This risk taking had an impact on the quality of bank assets, which had deteriorated. Banks find it difficult to recover part of the credits granted to customers, which should have been allocated to activities that are more profitable. On average, non-performing loans as a percentage of total loans were $15.118 \%^{21}$ over the period $2005-2015$. This high ratio slows down banking activities and reduces banks' profitability. This negative impact of credit risk on bank performance is in line with Bourke (1989), Molyneux and Thornton (1992), Iannotta et al. (2007), Barros et al. (2007), and Chiorazzo et al. (2008).

\section{Conclusion and policy recommendations}

The objective of this paper was to examine the impact of internal governance on bank performance. To do this, we used annual data related to a sample of ten Tunisian commercial banks observed during the period 1998-2015 collected from both banks' annual reports and financial statements. The Generalized Method of Moments (GMM) was used to estimate the parameters of our econometric model.

As far as we know, there are no published empirical studies which combine, in the same econometric model, the new measures adopted since the 2007 crisis aimed at strengthening internal banking governance (in particular, risk monitoring committee, CEO Compensation, structure and size of the board of directors, etc.), especially for Tunisian banks, which are small and medium-sized.

Empirical results show that the size of the board of directors, the presence of independent directors on the board of directors, and the state's participation are correlated positively and significantly with the performance of Tunisian banks, measured by the net interest margin. However, the presence of both foreign and institutional investors and the CEO compensation considerably reduce their performance.

Our results have some interesting implications. First, to improve their performance, Tunisian banks should increase the number of independent directors, reduce the presence of foreign and institutional investors on their board of directors, and revise the structure of the remuneration of the CEO. Second, banks should also define the optimal number of directors representing the state in the total number of directors on their boards.

Our findings also prove that both the size of the bank and its credit risk are detrimental to their performance, and thus, the banks are encouraged to follow appropriate consolidation and restructuring strategies to loosen the size constraint. To reduce the negative effect of credit risk, Tunisian banks' managers should review the primacy given to traditional banking intermediation, and diversify their activities.

Like all researches, our study suffers from some limitations, including the fact that it is based on only ten banks. This sample seems very limited to infer its results as a comprehensive conclusion, especially considering that the Tunisian banking sector has 29

\footnotetext{
${ }^{21}$ According to the World Bank Development Indicators (WDI) online database, the value of 2008 does not exist. We calculated the corresponding percentage by linear interpolation; and it is equal to $15.4 \%$.
} 
active banks. In this research, we selected the most dynamic banks and those that are most involved in financing the economy. In addition, we limited ourselves solely to the use of internal governance variables without introducing external governance mechanisms. In a later study, we will focus on a comparative study of the effect of internal and external governance mechanisms at first, followed by combining internal and external mechanisms to have a global impact on bank performance.

\section{Abbreviations}

CBT: Central Bank of Tunisia; CEO: Chief Executive Officer; FSB: Financial Stability Board; GDP: Gross Domestic Product; NBI: Net Banking Income; SME: Small and Medium Enterprises; TSE: Tunis Stock Exchange

\section{Acknowledgements}

NA (Not Applicable).

\section{Authors' contributions}

The first author ND prepared the database; selected and defined variables used in our empirical investigation, presented the literature review and estimated the econometrical model. The second author KZ presented an overview of the Tunisian bank system, analyzed and discussed the empirical results, concluded and provided some managerial implications. Both authors read and approved the final manuscript.

\section{Authors' information}

Nesrine Djebali is a PhD candidate in Economics at the Faculty of Law, Economics and Management of Tunis el Manar, Tunisia. She conducted research related to credit risk management and Tunisian external debt. She is currently working on the corporate governance mechanisms, credit scoring and default risk estimation on Tunisian commercial banks. She published several academic papers in international reviews.

Khemais Zaghdoudi is an Associate Professor of Economics at the Faculty of Law, Economics and Management of Jendouba, Tunisia. He conducted researches related to Tunisian productive system, Tunisian financial system, financial development, financial structure and growth, Stock exchange, specialization and trade. He is currently working on the effect of bank risk taking on the performance of Tunisian Banks, Insurance and financing of the Tunisian economy, Relationship between banks and insurance, Regional bank and development, and socio-economic and environmental implications of foreign direct investment and trade liberalization. He published several academic papers in international reviews.

Funding

There is no funding source.

\section{Availability of data and materials}

Datasets used in this paper are available in World Bank Indicators (at the link https://data.worldbank.org/) and in the annual reports of each bank

\section{Competing interests}

The authors declare that they have no competing interests.

Received: 23 February 2018 Accepted: 12 March 2020

Published online: 25 April 2020

\section{References}

Adams R, Ferreira D (2007) A theory of friendly boards. J Financ 62(1):217-250 https://doi.org/10.1111/j.1540-6261.2007.01206.x Adams R, Mehran H (2003a) Is corporate governance different for Bank holding companies? FRBNY Econ Policy Rev 9:123142 https://doi.org/10.2139/ssrn.387561

Adams R, Mehran H (2003b) Board structure, banking firm performance and the Bank holding company organizational form. No 866, Proceedings from Federal Reserve Bank of Chicago. Published in Conference on Bank Structure and Competition (39th); corporate governance: implications for financial services firm, issue May, 408-422.

Adams R, Mehran H (2008) Corporate performance, board structure and its determinants in the banking industry. Federal Reserve Bank of New York, Staff Reports n³30 https://doi.org/10.2139/ssrn.1150266

Adams RB (2012) Governance and the financial crisis. Int Rev Financ 12(1):7-38

Aebi V, Sabato G, Schmid M (2012) Risk management, corporate governance, and bank performance in the financial crisis. J Bank Financ 36(12):3213-3226 https://doi.org/10.1016/j.jbankfin.2011.10.020

Andres P, Vallelado E (2008) Corporate governance in banking: the role of the board of directors. J Bank Financ 32(12):25702580 https://doi.org/10.1016/j.jbankfin.2008.05.008

Arellano M, Bond S (1991) Some tests of specification for panel data: Monte Carlo evidence and an application to employment equations. Rev Econ Stud 58(2):277-297 https://doi.org/10.2307/2297968

Arellano M, Bover O (1995) Another look at the instrumental variable estimation of error-components models. J Econ 68(1): 29-51 https://doi.org/10.1016/0304-4076(94)01642-D

Ataur MR, Jahurul I (2018) The impact of corporate governance on Bank performance: empirical evidence from Bangladesh. Glob J Manag Bus Res C Finance 18(8):48-54

Athanasoglou P, Brissimis S, Delis MD (2008) Bank-specific, industry-specific and macroeconomic determinants of bank profitability. J Int Financ Mark Inst Money 18(2):121-136 https://doi.org/10.1016/j.intfin.2006.07.001 
Barros C, Ferreira C, Williams J (2007) Analyzing the determinants of performance of best and worst European banks: a mixed logit approach. J Bank Finance 31:2189-2203 https://doi.org/10.1016/j.jbankfin.2006.11.010

Basuonya E, Mohamed K, Ahmed FE (2017) Ownership structure, board characteristics and Bank performance in the GCC Countries. ITMSOC Trans Innov Bus Eng 02:1-6

Belkhir M (2009a) Board of Directors' size and performance in the banking industry. Int J Manag Financ 5(2):201-221 https:// doi.org/10.1108/17439130910947903

Belkhir M (2009b) Board structure, ownership structure and firm performance: evidence from banking. Appl Financ Econ 19: 1581-1593 https://doi.org/10.1080/09603100902967561

Berger AN, DeYoung R, Genay H, Udell GF (2000) Globalization of financial institutions: Evidence from cross-border banking performance. Brookings-Wharton Papers on Financial Services 3:23-158.

Blundell R, Bond S (1998) Initial conditions and moment restrictions in dynamic panel data models. J Econ 87: 115-143. https://doi.org/10.1016/50304-4076(98)00009-8

Bourbonnais R (2009) Econométrie - Manuel, et exercices corrigés. Dunod, 7ème édition, 373p. ISBN: 978-2-10-052522-5.

Bourke P (1989) Concentration and other determinants of bank profitability in Europe; North America and Australia. J Bank Financ 13:65-79 https://doi.org/10.1016/0378-4266(89)90020-4

Brancato T, Hexter E, Newman K (2006): The role of US corporate boards in enterprise risk management. The conference board research report no. R-1390-06-RR. https://doi.org/10.2139/ssrn.941179

Caspar R (2016) Firm performance and comply or explain disclosure in corporate governance. Eur Manag J 34(3):202-222 https://doi.org/10.1016/..emj.2016.03.003

Cerasi V, Sebastian M, Leonardo G, Tommaso O (2017) : How post-crisis regulation has affected bank CEO compensation. BIS working papers no 630, monetary and economic department. https://doi.org/10.2139/ssm.2960191

Cerasi V, Oliviero T (2015) CEO compensation, regulation, and risk in banks: Theory and evidence from the financial crisis. Int J Centr Bank 11(3):241-297.

Cheng S (2008) Board size and the variability of corporate performance. J Financ Econo 87: 157-176.

Chen HK, Liao YC, Lin CY, Yen JF (2018) The effect of the political connections of government bank CEOs on bank performance during the financial crisis. J Financ Stab 36(c):130-143

Chenini H, Jarboui A (2016) Analysis of the impact of governance on Bank performance: case of commercial Tunisian banks. J Knowl Econ:1-25

Chiorazzo V, Milani C, Salvini F (2008) Income diversification and bank performance: evidence from Italian banks. J Financ Serv Res 33:181-203 https://doi.org/10.1007/s10693-008-0029-4

Coles J, Daniel N, Naveen L (2008) Boards: does one size fit all? J Financ Econ 87:329-356 https://doi.org/10.1016/j.jfineco. 2006.08.008

Cotter J, Anil S, Marc Z (1997) Do independent directors enhance target shareholder wealth during tender offers? J Financ Econ 43:195-218 https://doi.org/10.1016/50304-405X(96)00886-0

David EH, Mingyi H, Pedro M (2012) Matos corporate governance in the 2007-2008 financial crisis: evidence from financial institutions worldwide. J Corp Finan 18(2):389-411 https://doi.org/10.1016/j.jcorpfin.2012.01.005

Duggal R, Millar J (1999) Institutional ownership and firm performance: the case of bidder returns. J Corp Finance 5(2):103117 https://doi.org/10.1016/S0929-1199(98)00018-2

Fallatah Y, Dickins D (2012) Corporate governance and firm performance and value in Saudi Arabia. Afr J Bus Manag 6(36): 10025-10034 https://doi.org/10.5897/AJBM12.008

Fernandes C, Farinha J, Martins FV, Mateus C (2017) Bank governance and performance: A survey of the literature. J Bank Regul 19(3):236-256. https://doi.org/10.1057/s41261-017-0045-0

Fernandes C, Farinha J, Martins FV, Mateus C (2016) Supervisory boards, financial crisis and bank performance: do board characteristics matter? J Bank Regul 18(4):310-337. https://doi.org/10.1057/s41261-016-0037-5

Fogelberg L, Griffith JM (2000) Control and bank performance. J Financ Strateg Decis 13(3):63-69

García H, Gavila A, Santaba D (2009) What explains the low profitability of Chinese banks? J Bank Financ 33:2080-2092 https://doi.org/10.1016/j.jbankfin.2009.05.005

Griffith JM, Fogelberg L, Weeks HS (2002) CEO ownership, corporate control, and Bank performance. J Econ Financ 26(2):170183 https://doi.org/10.1007/BF02755984

Grove H, Patelli L, Victoravich LM, Xu P (2011) Corporate governance and performance in the wake of the financial crisis: Evidence from US commercial banks. Corp Governance Int Rev 19(5):418-436

Gulamhussen M, Guerreiro L (2009) The influence of foreign equity and board membership on corporate strategy and internal cost management in Portuguese banks. Manag Account Res 20:6-17 https://doi.org/10.1016/..mar.2008.10.006

Hakimi A, Zaghdoudi K (2017) Liquidity risk and bank performance: an empirical test for Tunisian banks. Bus Econ Res 7(1): 46-57. https://doi.org/10.5296/ber.v7i1.10524.

Hakimi A, Zaghdoudi K, Zaghdoudi T, Djebali N (2017) What threatens Tunisian banking stability? Bayesian model versus panel data analysis. Int I Bus Finance Res 11(2):21-37.

Haris M, Hongxing Y, Gulzara T, Hafiz MJ, Qurat UA (2019) Corporate governance, political connections, and Bank performance. Int J Financ Stud 7(62):1-37. https://doi.org/10.3390/ijfs7040062

lannotta G, Nocera G, Sironi A (2007) Ownership structure, risk and performance in the European banking industry. J Bank Fin 31(7):2127-2149. https://doi.org/10.1016/j.jbankfin.2006.07.013.

Jensen M (1993) The modern industrial revolution, exit and the failure of internal control systems. J Financ 48:831-880 https://doi.org/10.1111/j.1540-6261.1993.tb04022.x

Kou G, Chao X, Peng Y, Alsaadi FE, Herrera-Viedma E (2019) Machine learning methods for systemic risk analysis in financial sectors. Technol Econ Dev Econ 25(5):716-742 https://doi.org/10.3846/tede.2019.8740

La Porta R, Lopez S, Shleifer F (2002) Government ownership of banks. J Financ 57(1):265-301 https://doi.org/10.1111/15406261.00422

Laeven L, Levine R (2009) Corporate governance, regulation, and bank risk taking. J Financ Econ 93:259-275 https://doi.org/ 10.1016/j.jineco.2008.09.003

Lee Siew P, Mansor I (2015) Directors' remuneration, governance and performance: the case of Malaysian banks. Manag Financ 41:26-44 
Leightner J, Lovell C (1998) The impact of finance liberalization on the performance of Thai banks. J Econ Bus 50(2):115-131 https://doi.org/10.1016/S0148-6195(97)00073-8

Manas M, Saravanan P (2017) Performance implications of board size, composition and activity: empirical evidence from the Indian banking sector. Corp Governance Int J Bus Soc 17:466-489

Molyneux P, Thornton J (1992) Determinants of European bank profitability: a note. J Bank Finance 16(6):1173-1178 https:// doi.org/10.1016/0378-4266(92)90065-8

Mongiardino A, Plath C (2010) Risk governance at large banks: have any lessons been learned? J Risk Manag Financ Inst 3(2): $116-123$

Oxelheim L, Randoy T (2003) The impact of foreign board membership on firm value. J Bank Finance 27(12):2369-2392 https://doi.org/10.1016/S0378-4266(02)00395-3. Elsevier

Paquerot M (1997) Stratégies d'enracinement des dirigeants, performance de la firme et structures de contrôle. In: Le Gouvernement des Entreprises, Economica

Pathan S (2009) Strong boards, CEO power and bank risk-taking. J Bank Financ 33:1340-1350 https://doi.org/10.1016/j. jbankfin.2009.02.001

Pathan S, Faff R (2013) Does board structure in banks really affect their performance? J Bank Financ 37(5):1573-1589 https:/ doi.org/10.1016/j.jbankfin.2012.12.016

Pi L, Timme S (1993) Corporate control and bank efficiency. J Bank Financ 17:515-530 https://doi.org/10.1016/03784266(93)90050-N

Pinto M (2006) The role of institutional investor in the corporate governance. German working papers in law and economics. OECD Publishing, March 23.

Ruhul S, Arjomandi A, Heinz Seufert J (2016) Does corporate governance affect Australian banks' performance? J Int Financ Mark Inst Money 43:113-125

Sabato G (2010) Financial crisis: where did risk management fail? Int Rev Appl Financ Issues Econ 2:12-18 https://doi.org/10 $2139 /$ ssrn. 1460762

Sanjai B (2017) Financial crisis, corporate governance, and Bank capital. Cambridge University Press (2017). https://doi.org/10.1017/9781316756669.

Simpson W, Gleason AE (1999) Board structure, ownership, and financial distress in banking firms. Int Rev Econ Financ 8(3): 281-292 https://doi.org/10.1016/S1059-0560(99)00026-X

Staikouras PK, Staikouras CK, Agoraki MEK (2007) The effect of board size and composition on European bank performance. Eur J Law Econ 23(1):1-27

Wang W, Lu W, Lin Y (2012) Does corporate governance play an important role in BHC performance? Evidence from the US. Econ Model 29:751-760 https://doi.org/10.1016/j.econmod.2012.01.021

Zaghdoudi K, Hakimi A (2017) The determinants of liquidity risk: evidence from Tunisian banks. J Appl Finance Bank 7(2,5): $71-81$

\section{Publisher's Note}

Springer Nature remains neutral with regard to jurisdictional claims in published maps and institutional affiliations.

\section{Submit your manuscript to a SpringerOpen ${ }^{\circ}$ journal and benefit from:}

- Convenient online submission

- Rigorous peer review

- Open access: articles freely available online

- High visibility within the field

- Retaining the copyright to your article

Submit your next manuscript at $\boldsymbol{s p r i n g e r o p e n . c o m ~}$ 